\title{
A Novel ${ }^{18}$ F-Labeled Imidazo[2,1-b]benzothiazole (IBT) for High- C Contrast PET Imaging of $\beta$-Amyloid Plaques
}

\author{
3 Behrooz H. Yousefi, ${ }^{* \dagger}{ }^{\dagger}$ Alexander Drzezga, ${ }^{\dagger}$ Boris von Reutern, ${ }^{\dagger}$ André Manook, ${ }^{\dagger}$ Markus Schwaiger, \\ ${ }_{4}$ Hans-Jürgen Wester, ${ }^{\ddagger}$ and Gjermund Henriksen*, ${ }^{\dagger}$ \\ $5{ }^{\dagger}$ Department of Nuclear Medicine, Klinikum rechts der Isar, Technische Universität München, Ismaninger Strasse 22, 81675 \\ 6 München, Germany \\ $7{ }^{*}$ Lehrstuhl für Pharmazeutische Radiochemie, Walther-Meissner-Strasse 3, 85748 Garching, Germany
}

ABSTRACT: ${ }^{18} \mathrm{~F}$-labeled imidazo[2,1-b]benzothiazole $\left(\left[{ }^{18} \mathrm{~F}\right]\right.$ 8) was synthesized and evaluated as a tracer for cerebral $\beta$ amyloid deposits $(\mathrm{A} \beta)$ by means of positron emission tomography (PET). $\left[{ }^{18} \mathrm{~F}\right] 8$ exhibits a high affinity to $\mathrm{A} \beta$ and suitable brain uptake kinetics combined with a high metabolic stability in the brain. In a double transgenic APP/PS1 mouse

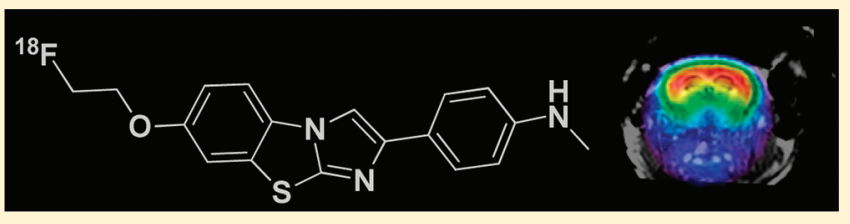
model of Alzheimer's disease, we demonstrated a specific uptake of $\left[{ }^{18} \mathrm{~F}\right] \mathbf{8}$ in $\mathrm{A} \beta$-containing telencephalic brain regions. The specific binding of $\left[{ }^{18} \mathrm{~F}\right] \mathbf{8}$ to $\mathrm{A} \beta$ was confirmed by regional brain biodistribution and autoradiography and correlated to immunohistochemistry staining. Analysis of brain sections of APP/ PS1 mouse injected with a cocktail of $\left[{ }^{18} \mathrm{~F}\right] \mathbf{8}$ and reference compound $\left[{ }^{3} \mathrm{H}\right] \mathrm{PiB}$ revealed that the two tracers bind to $\mathrm{A} \beta$ plaques in the brain of mouse in a comparable binding pattern. $\left[{ }^{18} \mathrm{~F}\right] \mathbf{8}$ represents the first high-contrast PET imaging agent for detection of $\mathrm{A} \beta$ plaques in transgenic mouse model of Alzheimer's disease and holds promise for transfer to a clinical evaluation.

KEYWORDS: Alzheimer's disease, ${ }^{18} \mathrm{~F}$-labeled tracer for $\beta$-amyloid, IBT, $\beta$-amyloid plaques, positron emission tomography, autoradiography, APP/PS1transgenic mice, neuroimaging

23 Current tracer development for the noninvasive imaging of 24 Alzheimer's disease $(\mathrm{AD})$ is focused on markers of senile 25 plaques (SP) that consist of $\beta$-amyloid peptides (A $\beta)$ with 26 positron emission tomography (PET) ${ }^{1-4}$ Several ${ }^{11} \mathrm{C}$ - and ${ }^{18} \mathrm{~F}$ 27 labeled PET tracers have been provided, including $\left(N-\left[{ }^{11} \mathrm{C}\right.\right.$ 28 methyl])-6-OH-BTA-1, Pittsburgh compound $\mathrm{B}\left(\left[{ }^{11} \mathrm{C}\right] \mathrm{PiB}\right.$, 29 1a), ${ }^{5}$ its ${ }^{18} \mathrm{~F}$-labeled analogue derivative $3^{\prime}-\left[{ }^{18} \mathrm{~F}\right] \mathrm{FPiB}$ (Flute30 metamol, GE-067, 1b), ${ }^{6,7}\left[{ }^{11} \mathrm{C}\right] \mathrm{SB}-13$ (1c) $){ }^{8}\left[{ }^{18} \mathrm{~F}\right]$ Florbetaben 31 (1d).$^{9,10}\left[{ }^{18} \mathrm{~F}\right]$ Florbetapir (1e),${ }^{11-13}\left[{ }^{18} \mathrm{~F}\right] \mathrm{BF} 228$ (1f) $){ }^{14}$ and $32\left[{ }^{18} \mathrm{~F}\right] \mathrm{FDDNP}^{15}$ (1g) (Scheme 1).

33 Currently available ${ }^{18}$ F-labeled compounds $\left(t_{1 / 2}=109.7\right.$ $34 \mathrm{~min})$ are hampered by a higher unspecific binding, i.e. to white 35 matter, as compared to their ${ }^{11} \mathrm{C}$-labeled analogues $\left(t_{1 / 2}=20.3\right.$ $36 \mathrm{~min})$. Thus, despite the high concentrations of $\mathrm{A} \beta$ in advanced $37 \mathrm{AD}$ cases, the tracer uptake ratios $\mathrm{AD}$ patients/healthy controls 38 of $\left[{ }^{18} \mathrm{~F}\right] \mathrm{FDDNP},{ }^{18}[\mathrm{~F}]$ Florbetaben, and $\left[{ }^{11} \mathrm{C}\right] \mathrm{PiB}$ in brain 39 regions known to contain $\mathrm{A} \beta$ have been found to be $1.3,{ }^{15} 1.5,{ }^{9}$ 40 and $2,5,16$ respectively.

41 Further development in the field of $\mathrm{A} \beta$ imaging aims at 42 providing tracers for $\mathrm{A} \beta$ with improved opportunity for 43 detection of less extensive amyloid pathology, that is, in 44 patients that are not yet in an advanced clinical stage. 45 Therefore, new pharmacophores suitable for ${ }^{18} \mathrm{~F}$-labeling with 46 improved brain uptake and clearance kinetics, combined with 47 high metabolic stability in vivo and high binding affinity to $\mathrm{A} \beta$ 48 plaques, are required for advances in the field of $\mathrm{A} \beta$-targeted 49 radiopharmaceuticals.
Recently, we reported the synthesis and evaluation of ${ }^{11} \mathrm{C}-50$ labeled imidazo[2,1-b] benzothiazoles (IBTs) as a new 51 pharmacophore for imaging $\mathrm{A} \beta \cdot{ }^{17}$ Here, we report the synthesis 52 and evaluation of a novel ${ }^{18} \mathrm{~F}$-labeled 2 - $(p$-methylaminophen- 53 yl)-7-(2-fluoroethoxy)imidazo[2,1-b] benzothiazole ([ $\left[{ }^{18} \mathrm{~F}\right] \mathrm{IBT}, 54$ $\left.\left[{ }^{18} \mathrm{~F}\right] \mathbf{8}\right)$. Compound 8 was compared with $\mathbf{1 a}$ for binding 55 affinity to $\mathrm{A} \beta$ fibrils in vitro, and $\left[{ }^{18} \mathrm{~F}\right] 8$ was used for the 56 evaluation of brain uptake kinetics in Balb-C mice. 57 Furthermore, the properties of $\left[{ }^{18} \mathrm{~F}\right] \mathbf{8}$ were investigated in an 58 $\mathrm{APP} / \mathrm{PS} 1$ transgenic mouse model of $\mathrm{AD}$ by means of in vivo 59 $\mu \mathrm{PET} / \mathrm{CT}$, dual-tracer autoradiography, regional brain biodis- 60 tribution, and immunohistochemistry.

The IBTs 3-8, obtained in moderate to excellent isolated 62 yield $(35-95 \%)$ in a high purity (>95\% by HPLC), were 63 characterized by means of LC-MS and NMR. The IBT 64 derivative 3 was synthesized by direct coupling of 6- 65 methoxybenzo[d]thiazol-2-amine and $N$-(4-(2-bromoacetyl)- 66 phenyl)acetamide $\mathbf{2}$ in ethanol at reflux temperature (Scheme $67 \mathrm{~s} 2$ 2). Compound 3 was deacetylated by treatment with $2 \mathrm{M}_{68} \mathrm{~s} 2$ $\mathrm{NaOH}$ at $100{ }^{\circ} \mathrm{C}$ for $30 \mathrm{~min}$ under microwave heating. 69 Intermediate 4 was methylated using $\mathrm{MeI}$ in $\mathrm{DMF}$ to yield 5. 70 Compound 5 was demethylated by $\mathrm{BBr}_{3}$ in $\mathrm{CH}_{2} \mathrm{Cl}_{2}$ using 71 microwave irradiation at $120{ }^{\circ} \mathrm{C}$ for $30 \mathrm{~min}$ to yield 6 .

Received: March 30, 2011

Accepted: July 19, 2011

Published: July 19, 2011 
Scheme 1. PET Tracers Evaluated in Clinical Trials<smiles>CNc1ccc(/C=C/c2ccc(O)cc2)cc1</smiles>

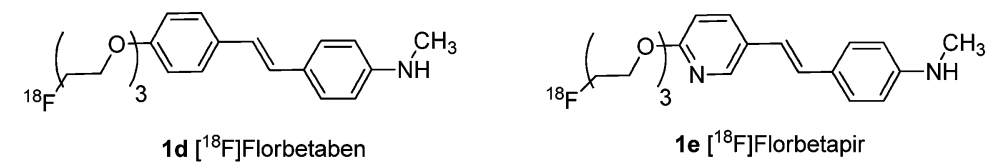<smiles>CN(C)c1ncc(/C=C/c2ccc(OCC[18F])cc2)s1</smiles><smiles>CC(=C(C#N)C#N)c1ccc2cc(N(C)CC[I+])ccc2c1</smiles>

$\lg \left[{ }^{18}\right.$ F $]$ FDDNP

Scheme 2. Synthesis and Radiosynthesis of IBT $8^{a}$

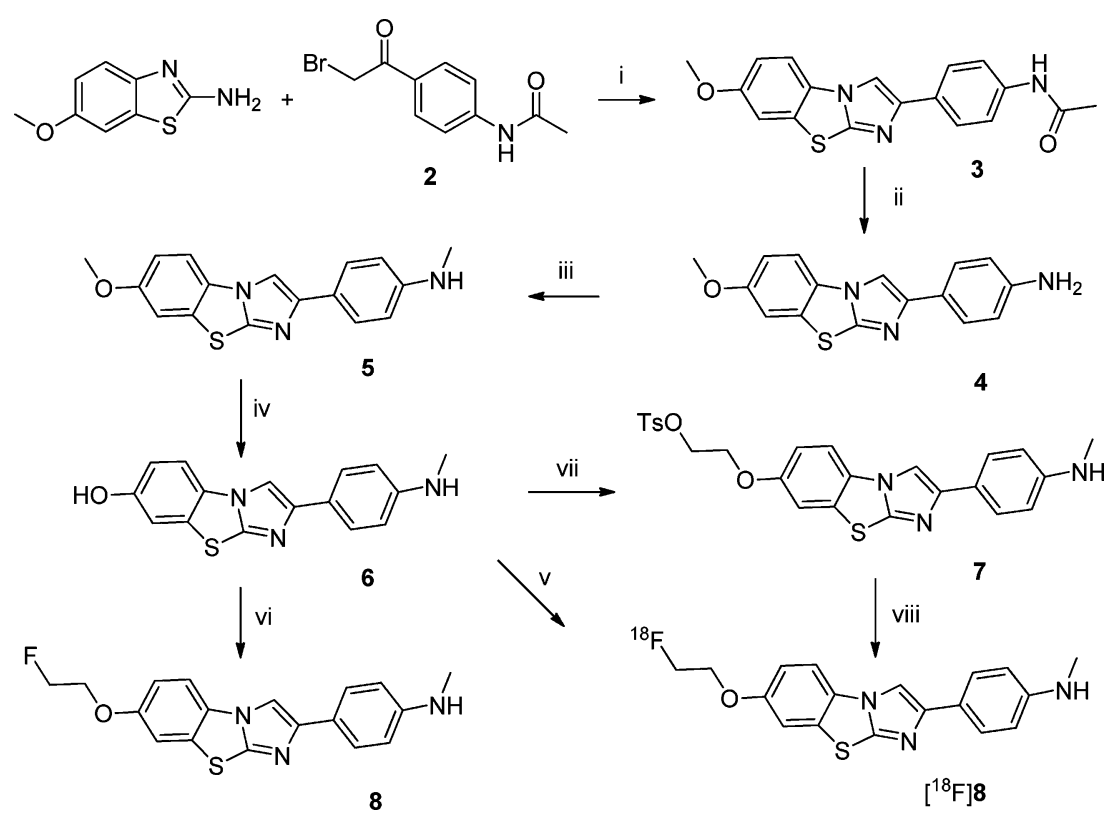

${ }^{a}$ Reagents and conditions: (i) EtOH, reflux, $2 \mathrm{~h}$. (ii) $2 \mathrm{M} \mathrm{NaOH}, 100{ }^{\circ} \mathrm{C}, \mathrm{MW}, 30 \mathrm{~min}$. (iii) DMF, $\mathrm{MeI}, 90{ }^{\circ} \mathrm{C} .(\mathrm{iv}) \mathrm{BBr}_{3}$ in $\mathrm{CH}_{2} \mathrm{Cl}_{2}, \mathrm{MW}^{\circ} 120{ }^{\circ} \mathrm{C}$, 30 min. (v) NaH, DMF, $\left[{ }^{18} \mathrm{~F}\right] \mathrm{FEtTs}, 90^{\circ} \mathrm{C}, 5 \mathrm{~min}$. (vi) $\mathrm{NaH}$ in DMF, $\mathrm{F}\left(\mathrm{CH}_{2}\right)_{2} \mathrm{Br}, 80^{\circ} \mathrm{C}, 15 \mathrm{~min}$. (vii) $\mathrm{K}_{2} \mathrm{CO}_{3}$ in DMF, ethylene glycol ditosylate, $100{ }^{\circ} \mathrm{C}, 15$ min. (viii) DMF: $\mathrm{CH}_{3} \mathrm{CN}(1: 5),\left[\mathrm{K}^{+} / 2.2 .2\right]^{18} \mathrm{~F}^{-}, 120{ }^{\circ} \mathrm{C}, 20 \mathrm{~min}$.

73 The IBT scaffold is an electron-rich heteroaromatic system 74 with a lipophilicity value ${ }^{17}$ suitable for in vivo imaging of targets 75 in the brain. A further advantage is the opportunity of 76 introducing the ${ }^{18} \mathrm{~F}$-label by means of an ${ }^{18} \mathrm{~F}$-fluoroalkyl 77 group connected to the phenolic oxygen. In this study, 78 compound 6 was directly reacted with $\mathrm{F}\left(\mathrm{CH}_{2}\right)_{2} \mathrm{Br}$ to yield 8 79 and also with ethylene glycol ditosylate to yield the precursor ${ }_{80}$ for one-step radiofluorination (7) in DMF. For the radiosyn${ }_{81}$ thesis, 7 was reacted with $\left[\mathrm{K}^{+} / 2.2 .2\right]{ }^{18} \mathrm{~F}^{-}$to yield $\left[{ }^{18} \mathrm{~F}\right] 8$ after $8220 \mathrm{~min}$ at $120{ }^{\circ} \mathrm{C}$ in DMF: $\mathrm{CH}_{3} \mathrm{CN}$ (1:5). The one-step 83 procedure provided $\left[{ }^{18} \mathrm{~F}\right] 8$ in a moderate radiochemical yield ${ }_{84}(24 \pm 5 \%)$. Alternatively, $\left[{ }^{18} \mathrm{~F}\right] 8$ was prepared in a high ${ }_{85}$ radiochemical yield via a two-step ${ }^{18}$ F-fluorination (radio86 chemical yield, $58 \pm 4 \%$; total synthesis time, $55 \mathrm{~min}$ ). Both 87 procedures provided $\left[{ }^{18} \mathrm{~F}\right] 8$ in a high radiochemical $(>99 \%)$ 88 and chemical purity.
For the determination of binding affinity of 8 to $\mathrm{A} \beta$, fibrils of 89 $\mathrm{A} \beta_{1-40}$ and $\mathrm{A} \beta_{1-42}$ were prepared from the respective 90 monomers according to a published procedure. ${ }^{18}$ The presence 91 of fibrils was confirmed by transmission electron microscopy at 92 10 and $100 \mu \mathrm{M}$ concentration. The inhibition constants, $K_{\mathrm{i}}$, of 93 8 and of 1a versus $\left[{ }^{3} \mathrm{H}\right] \mathbf{1} \mathbf{a}$ are presented in Table 1.

$94 \mathrm{t} 1$

The brain uptake kinetics of $\left[{ }^{18} \mathrm{~F}\right] \mathbf{8}$ was compared to that of 95 $\left[{ }^{11} \mathrm{C}\right] \mathbf{1 a}$ at 5 and $30 \mathrm{~min}$ postinjection (Figure 1) in Balb-C $96 \mathrm{fl}$ mice $(n \geq 4)$. The measure of lipophilicity of $\left[{ }^{18} \mathrm{~F}\right] 8$ was 97 determined at $\mathrm{pH} 7.4: \log P_{\text {oct } / \mathrm{PBS}}=1.92(n=6)$.

Table 1. $K_{\mathrm{i}}$ Values $(\mathrm{nM} ; \boldsymbol{x} \pm \mathrm{SD}, n=2)$ Determined for Inhibition of $\left[{ }^{3} \mathrm{H}\right] 1 \mathrm{a}$ Binding to $\mathrm{A} \beta$ Fibrils

\begin{tabular}{ccr} 
compound & $\mathbf{8}$ & \multicolumn{1}{c}{$\mathbf{1 a}$} \\
$K_{\mathrm{i}} \mathrm{A} \beta_{1-40}$ & $2.1 \pm 0.8$ & $12.0 \pm 3.2$ \\
$K_{\mathrm{i}} \mathrm{A} \beta_{1-42}$ & $3.2 \pm 0.6$ & $7.7 \pm 2.0$
\end{tabular}




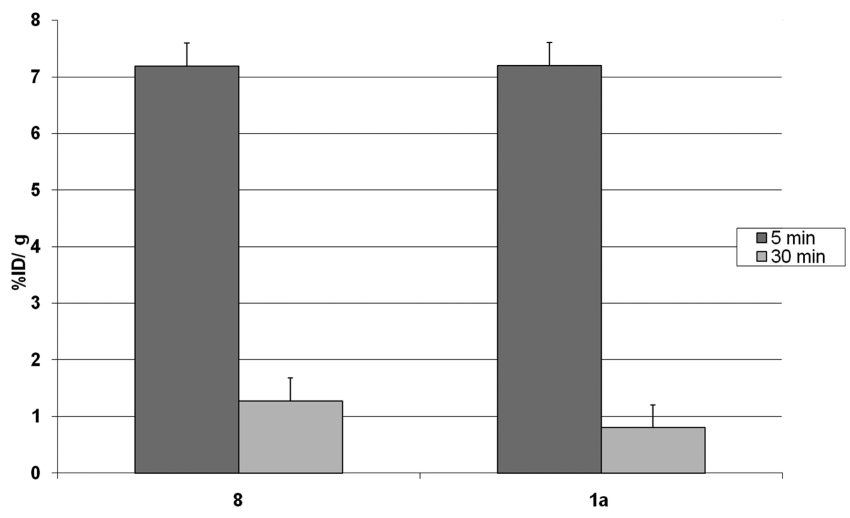

Figure 1. Brain uptake of $\left[{ }^{18} \mathrm{~F}\right] \mathbf{8}$ as compared to that of the reference $\left[{ }^{11} \mathrm{C}\right] \mathbf{1 a}$ in male Balb-C mice at 5 and 30 min postinjection (mean \pm $\mathrm{SD}, n \geq 4)$.

99 For comparison, the key preclinical data of a currently 100 advancing ${ }^{18} \mathrm{~F}$-labeled tracer for $\mathrm{A} \beta,\left[{ }^{18} \mathrm{~F}\right]$ Florbetapir, were 101 reportedly $^{13}$ an in vitro binding affinity to $\mathrm{A} \beta$ aggregates in 102 postmortem $\mathrm{AD}$ brain homogenates of $2.87 \pm 0.17 \mathrm{nM}$, an 103 initial uptake of $6.2 \% \mathrm{ID} / \mathrm{g}$ at $2 \mathrm{~min}$ pi and $1.84 \% \mathrm{ID} / \mathrm{g}$ at 60 $104 \mathrm{~min}$ in male mice. The brain uptake kinetics measurements in 105 Balb-C mice at 5 and $30 \mathrm{~min}$ pi of $\left[{ }^{18} \mathrm{~F}\right] \mathbf{8}$ and $\left[{ }^{11} \mathrm{C}\right] \mathbf{1 a}$ show the 106 desirable characteristics for an in vivo amyloid imaging agent 107 with an excellent initial brain uptake and rapid clearance 108 properties.

109 The metabolic stabilities of $\left[{ }^{18} \mathrm{~F}\right] \mathbf{8}$ and $\left[{ }^{11} \mathrm{C}\right] \mathbf{1 a}$ from in vivo 110 experiments with Balb-C mice at 10 and $30 \mathrm{~min}$ pi in samples 111 of blood and brain tissue were determined as reported 112 elsewhere, ${ }^{17,19}$ and the results are given in Table 2 .

Table 2. Speciation of Radioactivity in Brain and Blood of Mice Injected with $\left[{ }^{18} \mathrm{~F}\right] 8$ and $\left[{ }^{11} \mathrm{C}\right] 1 \mathrm{a}$ (\% Intact Tracer ${ }^{a}$ )

\begin{tabular}{|c|c|c|c|c|}
\hline \multirow[b]{2}{*}{ tissue } & \multicolumn{2}{|c|}{ blood } & \multicolumn{2}{|c|}{ brain } \\
\hline & $10 \mathrm{~min}$ & $30 \mathrm{~min}$ & $10 \mathrm{~min}$ & $30 \mathrm{~min}$ \\
\hline$\left[{ }^{18} \mathrm{~F}\right] 8$ & $12 \pm 3$ & $5 \pm 4$ & $92 \pm 4$ & $88 \pm 6$ \\
\hline$\left[{ }^{11} \mathrm{C}\right] \mathbf{1} \mathbf{a}$ & $20 \pm 5$ & $11 \pm 2$ & $96 \pm 1$ & $92 \pm 3$ \\
\hline
\end{tabular}

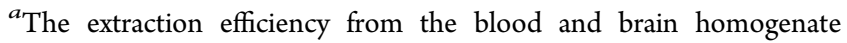
samples was $64-95 \%$.
In vivo $\mathrm{A} \beta$ imaging with $\left[{ }^{18} \mathrm{~F}\right] 8$ in $\mathrm{Tg}$ mice and cross- 113 confirmation of its imaging properties with ex vivo experiments 114 were performed by employing homozygous animals of the 115 APP/PS1 AD mouse model. ${ }^{20}$ A multimodal approach was 116 followed, including $\mu \mathrm{PET} / \mathrm{CT}$, ex vivo regional brain 117 biodistribution, and dual-tracer digital autoradiography. For 118 the PET studies, Tg animals $(24.0 \pm 0.4$ months old; body 119 weight, $34.5 \pm 3.6 \mathrm{~g} ; n=7)$ were injected with a single bolus of 120 $\left[{ }^{18} \mathrm{~F}\right] \mathbf{8}(11.7 \pm 4.1 \mathrm{MBq})$. Age-matched C57B6/J (25 \pm 2121 months old; body weight, $34.8 \pm 3.0 \mathrm{~g} ; n=3$ ) were used as 122 controls and received a single bolus injection of $\left[{ }^{18} \mathrm{~F}\right] 8(11.5 \pm 123$ 3.4 MBq). The PET images (Figure 2) were generated as $124 \mathrm{f} 2$ summed frames from 36 to $45 \mathrm{~min}$ pi. To obtain the anatomical 125 reference, the CT image obtained in the PET/CT sequence 126 was overlaid with a cerebral MRI template of an age-, gender-, 127 and weight-matched $\mathrm{Tg}$ /control mouse (Figure 2). 128

The brain uptake kinetics in $\mathrm{Tg}$ animals and controls as 129 measured by means of $\mu$ PET are presented in Figure 3A. The $130 \mathrm{f} 3$ time-radioactivity curves (TACs) from whole cortex and 131 cerebellum and the cortex/cerebellum ratio curves in $\mathrm{Tg}$ and 132 C57BL/6J control mice were calculated (Figure 3B). 133

For the multimodal analysis, a 25 months old Tg mouse was 134 coinjected with a mixture of $13.5 \mathrm{MBq}\left[{ }^{18} \mathrm{~F}\right] \mathrm{8}$ and $4.0 \mathrm{MBq} 135$ $\left[{ }^{3} \mathrm{H}\right] 1 \mathrm{a}$ into a tail vein and first scanned with a Siemens Inveon 136 $\mu \mathrm{PET} / \mathrm{CT}$ for $45 \mathrm{~min}$ in list mode. The control (28 months 137 old) mouse received a mixture of $10.0 \mathrm{MBq}\left[{ }^{18} \mathrm{~F}\right] 8$ and 3.7138 $\mathrm{MBq}\left[{ }^{3} \mathrm{H}\right]$ 1a. Animals were killed at $45 \mathrm{~min}$ postinjection. 139 Analysis of the data from dual-label autoradiography (tritium 140 and fluorine-18) and brain biodistribution verified the cortical 141 uptake of $\left[{ }^{18} \mathrm{~F}\right] 8$ seen in the PET studies and also that the 142 uptake of $\left[{ }^{18} \mathrm{~F}\right] 8$ represents a true binding of $\left[{ }^{18} \mathrm{~F}\right] 8$ to cortical 143 A $\beta$ plaques. Furthermore, the binding profile of fluorine-18 144 autoradiography channels is consistent with that of 1a (Figure $145 \mathrm{f} 4$ 4) as well as with that of the results from $\mathrm{A} \beta$ immunohis- $146 \mathrm{f4}$ tochemistry (IHC).

On the basis of the results from $\mu \mathrm{PET} / \mathrm{CT}$ and ex vivo 148 experiments in this $\mathrm{Tg}$ mouse model, we conclude that $\left[{ }^{18} \mathrm{~F}\right] 8$ has a specific binding to $\mathrm{A} \beta$ plaques in hippocampal and 150 cortical regions. The time-activity curves (TACs) evidenced an 151 excellent brain uptake and clearance profile. From 5 min pi on 152 to the end of the PET examination (45 min), an excellent 153 differentiation of cortex and cerebellum was observed in $\mathrm{Tg} 154$ animals. In contrast, the ratio of tracer uptake in cortex relative 155

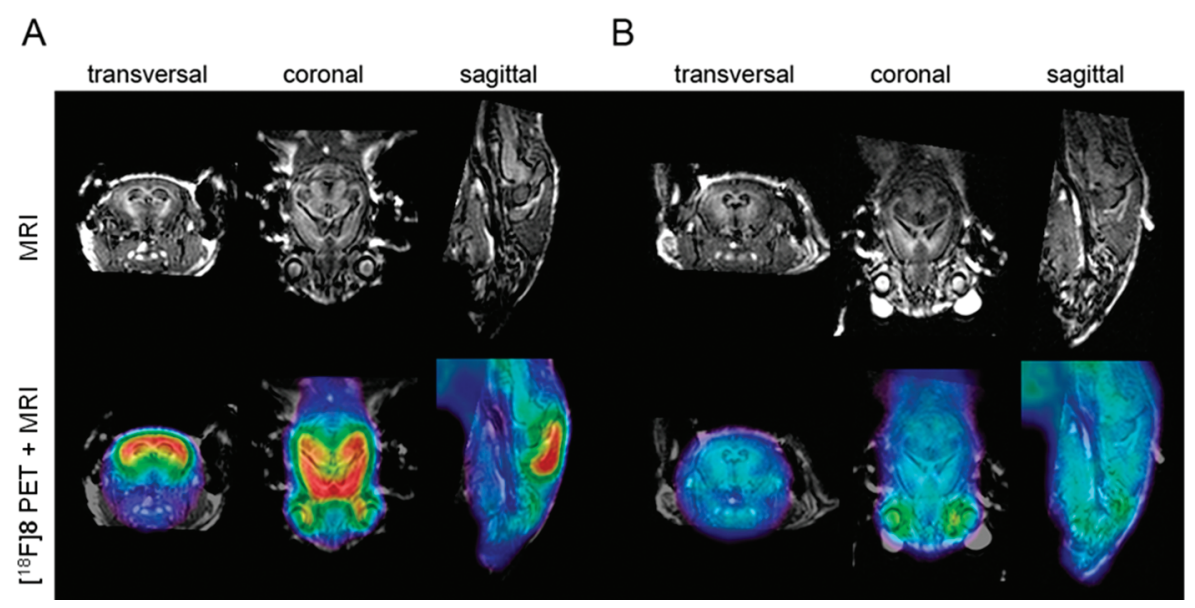

Figure 2. Orthogonal $\mu \mathrm{PET}$ images superimposed onto a MRI template. The PET signal represents the summed frames 36-45 min postinjection of $\left[{ }^{18} \mathrm{~F}\right] 8$ in (A) $\mathrm{Tg}$ and (B) control (coregistered $\mu \mathrm{PET}$ images of all animals in each experimental group were summed to generate these images). 
A

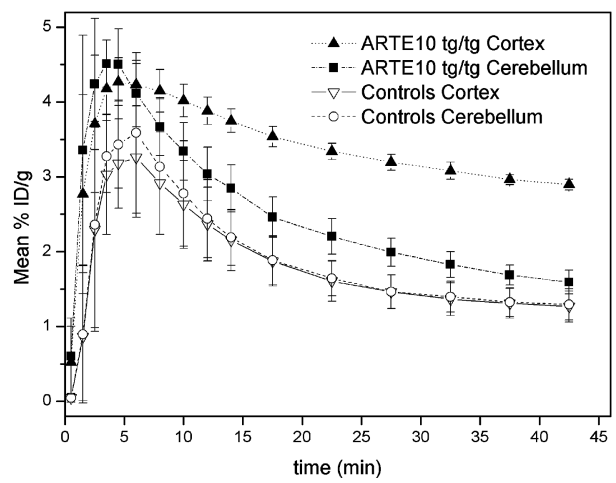

$\mathrm{B}$

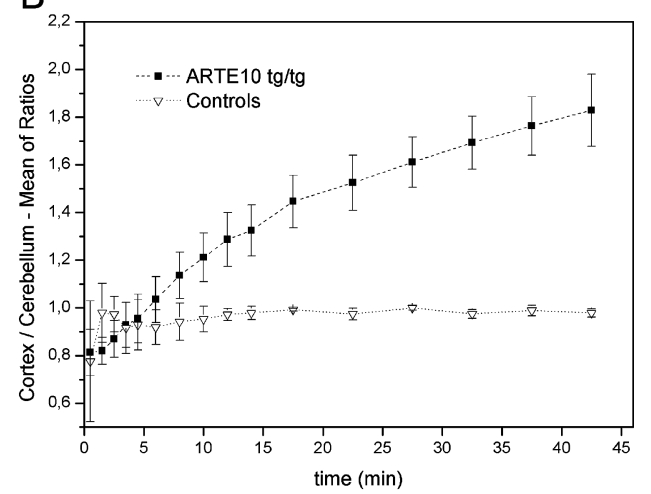

Figure 3. (A) $\mu$ PET mean TACs from cortical and cerebellar VOIs in $\mathrm{Tg}(n=7)$ and control mice $(n=3)$ of $\left[{ }^{18} \mathrm{~F}\right] \mathbf{8}$. (B) Mean of ratios in $\mathrm{Tg}(n=$ 7) and control mice $(n=3)$ of $\left[{ }^{18} \mathrm{~F}\right] 8$.
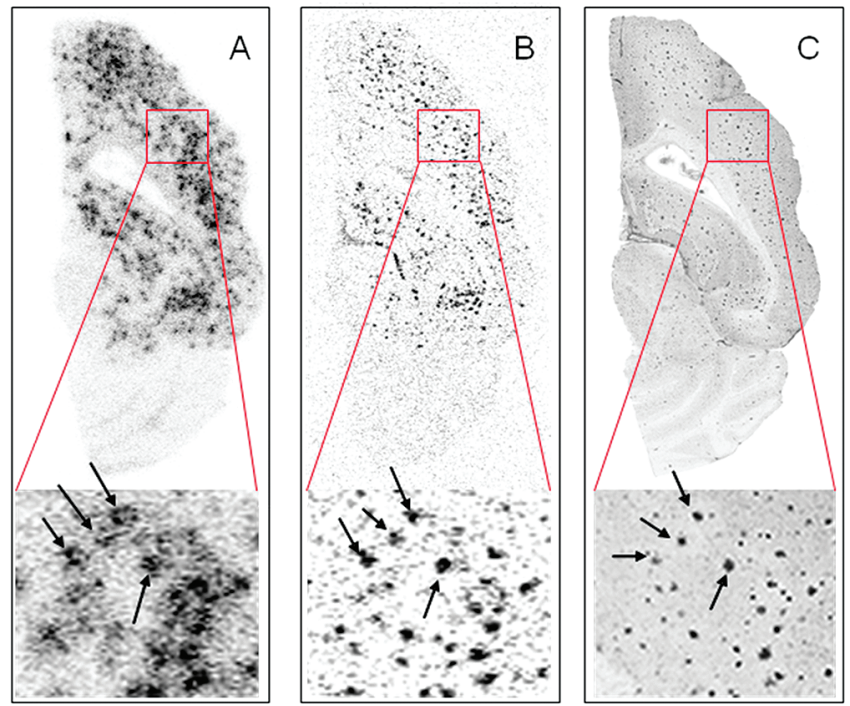

Figure 4. Ex vivo dual-tracer autoradiography of a $12 \mu \mathrm{m}$ thick axial section of $\mathrm{Tg}$ mouse brain killed $45 \mathrm{~min}$ after coinjection of $\left[{ }^{18} \mathrm{~F}\right] 8$ and $\left[{ }^{3} \mathrm{H}\right] 1$ a superimposed to the optical image. (A) Separated image of $\left[{ }^{18} \mathrm{~F}\right] \mathbf{8}$ autoradiography. (B) Separated image of $\left[{ }^{3} \mathrm{H}\right] \mathbf{1 a}$ autoradiography. (C) Fused IHC images of anti-A $\beta_{40}$ and anti-A $\beta_{42}$ (gray scale).

156 to cerebellum in controls animals approaches unity. The 157 potential of $\left[{ }^{18} \mathrm{~F}\right] 8$ as a tracer for $\mathrm{A} \beta$ is strengthened by the 158 results from the ex vivo regional brain biodistribution and 159 comparison to $\left[{ }^{3} \mathrm{H}\right] \mathbf{1 a}$ in dual-tracer autoradiography experi160 ments. It was confirmed that $\left[{ }^{18} \mathrm{~F}\right] \mathbf{8}$ and $\left[{ }^{3} \mathrm{H}\right] \mathbf{1 a}$ bind in a 161 similar manner to brain of APP/PS1 Tg mice. A PET study of 162 the performance of $\left[{ }^{18} \mathrm{~F}\right] 8$ in a younger cohort of $\mathrm{Tg}$ mice is 163 currently in progress.

164 This proof of concept study demonstrates that the 165 imidazo $[2,1-b]$ benzothiazole $\left[{ }^{18} \mathrm{~F}\right] \mathbf{8}$ allows high-contrast imag166 ing of $\mathrm{A} \beta$ in an APP/PS1 mouse model of $\mathrm{AD}$ by means of $167 \mu$ PET. The favorable properties of an efficient and rapid ${ }^{18} \mathrm{~F}$ 168 labeling combined with an excellent brain entry/clearance 169 kinetics as well as a high affinity for the amyloid- $\beta$ plaques and 170 high in vivo stability justify the further evaluation of this 171 compound for the detection of amyloid plaques in the living 172 brain at an early stage of the disease.

\section{ASSOCIATED CONTENT}

Full experimental details for compounds synthesized, proce- 175 dures for radiosynthesis, $\log P_{\text {oct/PBS }}$ measurements, description 176 of assays, metabolite analyses, HPLC purity tests, animal 177 studies, PET imaging, and ex vivo evaluation of control mouse. 178 This material is available free of charge via the Internet at 179 http://pubs.acs.org.

180

\section{AUTHOR INFORMATION}

181

\section{Corresponding Authors}

182

*Tel: +49 89 4140-6340. Fax: +49 89 4140-6493. E-mail: b. 183 yousefi@tum.de (B.H.Y.).

184 *Tel: +4989 4140-4586. Fax: +49 89 4140-4841. E-mail: G. 185 Henriksen@lrz.tum.de (G.H.).

186

\section{Funding}

187

This work was supported by grants from Deutsche For- 188 schungsgemeinschaft (DFG) (HE4560/1-2, DR 445/3-1, DR 189 445/4-1, and IRTG 1373).

190

\section{ACKNOWLEDGMENTS}

191

We thank Katrina McGuire, Andrea Alke, Monika Beschorner, 192 Sybille Reder, Axel Weber, and Markus Lehmann for their 193 excellent technical support; Antje Willuweit, Michael Schoor, 194 Heinz von der Kammer for provision of APP/PS1 (Arte10) 195 animals and their scientific support for IHF; and Prof. Axel 196 Walch and his group for excellent technical support for 197 fluorescence microscopy.

\section{REFERENCES}

199

(1) Selkoe, D. J. Toward a comprehensive theory for Alzheimer's 200 disease. Hypothesis: Alzheimer's disease is caused by the cerebral 201 accumulation and cytotoxicity of amyloid beta-protein. Ann. N.Y. Acad. 202 Sci. 2000, 924, 17-25.

(2) Klunk, W. E. Biological markers of Alzheimer's disease. Neurobiol. 204 Aging 1998, 19 (2), 145-147.

(3) Selkoe, D. J. Alzheimer's disease: Genes, proteins, and therapy. 206 Physiol. Rev. 2001, 81 (2), 741-766.

(4) Selkoe, D. J. Imaging Alzheimer's amyloid. Nat Biotechnol 2000, 208 18 (8), 823-824.

(5) Klunk, W. E.; Engler, H.; Nordberg, A.; Wang, Y.; Blomqvist, G.; 210 Holt, D. P.; Bergstrom, M.; Savitcheva, I.; Huang, G. F.; Estrada, S.; 211 Ausen, B.; Debnath, M. L.; Barletta, J.; Price, J. C.; Sandell, J.; Lopresti, 212 B. J.; Wall, A.; Koivisto, P.; Antoni, G.; Mathis, C. A.; Langstrom, B. 213 Imaging brain amyloid in Alzheimer's disease with Pittsburgh 214 Compound-B. Ann. Neurol. 2004, 55, 306-319. 
216 (6) Koole, M.; Lewis, D. M.; Buckley, C.; Nelissen, N.; 217 Vandenbulcke, M.; Brooks, D. J.; Vandenberghe, R; Laere, K. V. 218 Whole-body biodistribution and radiation dosimetry of ${ }^{18} \mathrm{~F}-\mathrm{GE} 067$ : A 219 radioligand for in vivo brain amyloid imaging. J. Nucl. Med. 2009, 50, $220818-822$.

(7) Nelissen, N.; Laere, K. V.; Thurfjell, L.; Owenius, R.; 222 Vandenbulcke, M.; Koole, M.; Bormans, G.; Brooks, D. J.; 223 Vandenberghe, R. Phase 1 Study of the Pittsburgh Compound B 224 Derivative ${ }^{18} \mathrm{~F}$-Flutemetamol in Healthy Volunteers and Patients with 225 Probable Alzheimer Disease. J. Nucl. Med. 2009, 50, 1251-1259.

226 (8) Henriksen, G.; Yousefi, B. H.; Drzezga, A.; Wester, H.-J. 227 Development and evaluation of compounds for imaging of beta228 amyloid plaque by means of positron emission tomography. Eur. J. 229 Nucl. Med. Mol. Imaging 2008, 35 (Suppl. 1), S75-S81.

230 (9) Rowe, C. C.; Ackerman, U.; Browne, W.; Mulligan, R.; Pike, K. 231 L.; O'Keefe, G.; Tochon-Danguy, H.; Chan, G.; Berlangieri, S. U.; 232 Jones, G.; Dickinson-Rowe, K. L.; Kung, H. P.; Zhang, W.; Kung, M. 233 P.; Skovronsky, D.; Dyrks, T.; Holl, G.; Krause, S.; Friebe, M.; 234 Lehman, L.; Lindemann, S.; Dinkelborg, L. M.; Masters, C. L.; 235 Villemagne, V. L. Imaging of amyloid beta in Alzheimer's disease with $236{ }^{18}$ F-BAY94-9172, a novel PET tracer: proof of mechanism. Lancet 237 Neurol. 2008, 7 (2), 129-135.

(10) O'Keefe, G. J.; Saunder, T. H.; Ng, S.; Ackerman, U.; Tochon239 Danguy, H. J.; Chan, J. G.; Gong, S.; Dyrks, T.; Lindemann, S.; Holl, 240 G.; Dinkelborg, L.; Villemagne, V.; Rowe, C. C. Radiation Dosimetry 241 of $\beta$-Amyloid Tracers ${ }^{11} \mathrm{C}-\mathrm{PiB}$ and ${ }^{18} \mathrm{~F}-\mathrm{BAY} 94-9172$. J. Nucl. Med. 242 2009, 50, 309-315.

243 (11) Wong, D. F.; Rosenberg, P. B.; Zhou, Y.; Kumar, A.; Raymont, 244 V.; Ravert, H. T.; Dannals, R. F.; Nandi, A.; Brail, J. B.; Ye, W.; Hilton, 245 J.; Lyketsos, C.; Kung, H. F.; Joshi, A. D.; Skovronsky, D. M.; 246 Pontecorvo, M. J. In Vivo Imaging of Amyloid Deposition in 247 Alzheimer Disease Using the Radioligand 18F-AV-45 (Flobetapir F 248 18). J. Nucl. Med. 2010, 51, 913-920.

249 (12) Kung, H. F.; Choi, S. R.; Qu, W.; Zhang, W.; Skovronsky, D. ${ }^{18}$ F 250 Stilbenes and Styrylpyridines for PET Imaging of A $\beta$ Plaques in 251 Alzheimer's Disease: A Miniperspective. J. Med. Chem. 2010, 53, 933252941.

253 (13) Choi, S. R.; Golding, G.; Zhuang, Z.; Zhang, W.; Lim, N.; Hefti, 254 F.; Benedum, T. E.; Kilbourn, M. R.; Skovronsky, D.; Kung, H. F. 255 Preclinical Properties of 18F-AV-45: A PET Agent for A $\beta$ Plaques in 256 the Brain. J. Nucl. Med. 2009, 50, 1887-1894.

257 (14) Kudo, Y.; Okamura, N.; Furumoto, S.; Tashiro, M.; Furukawa, 258 K.; Maruyama, M.; Itoh, M.; Iwata, R.; Yanai, K.; Arai, H. 2-(2-[2259 Dimethylaminothiazol-5-yl] ethenyl)-6- (2-[fluoro] ethoxy)260 benzoxazole: A novel PET agent for in vivo detection of dense 261 amyloid plaques in Alzheimer's disease patients. J. Nucl. Med. 2007, 48, $262553-561$.

(15) Thompson, P. W.; Ye, L.; Morgenstern, J. L.; Sue, L.; Beach, T. 264 G.; Judd, D. J.; Shipley, N. J.; Libri, V.; Lockhart, A. Interaction of the 265 amyloid imaging tracer FDDNP with hallmark Alzheimer's disease 266 pathologies. J. Neurochem. 2009, 109, 623-630.

267 (16) Pike, K. E.; Savage, G.; Villemagne, V. L.; Ng, S.; Moss, S. A.; 268 Maruff, P.; Mathis, C. A.; Klunk, W. E.; Masters, C. L.; Rowe, C. C. 269 Beta-amyloid imaging and memory in non-demented individuals: 270 Evidence for preclinical Alzheimer's disease. Brain 2007, 130, 28372712844.

272 (17) Yousefi, B. H.; Manook, A.; Drzezga, A.; von Reutern, B.; 273 Schwaiger, M.; Wester, H.-J.; Henriksen, G. Synthesis and Evaluation 274 of ${ }^{11} \mathrm{C}$-labeled Imidazo[2,1-b] benzothiazoles (IBTs) as PET tracers for 275 Imaging $\beta$-Amyloid Plaques in Alzheimer's Disease. J. Med. Chem. $2762011,54,949-956$.

(18) Lockhart, A.; Ye, L.; Judd, D. B.; Merritt, A. T.; Lowe, P. N.; 278 Morgenstern, J. L.; Hong, G.; Gee, A. D.; Brown, J. Evidence for the 279 presence of three distinct binding sites for the thioflavin $\mathrm{T}$ class of 280 Alzheimer's disease PET imaging agents on beta-amyloid peptide 281 fibrils. J. Biol. Chem. 2005, 280, 7677-7684.

282 (19) Henriksen, G.; Hauser, A. I.; Westwell, A. D.; Yousefi, B. H.; 283 Schwaiger, M.; Drzezga, A.; Wester, H.-J. Metabolically stabilized benzothiazoles for imaging of amyloid plaques. J. Med. Chem. 2007, 50, 284 $1087-1089$.

(20) Willuweit, A.; Velden, J.; Godemann, R.; Manook, A.; Jetzek, F.; 286 Tintrup, H.; Kauselmann, G.; Zevnik, B.; Henriksen, G.; Drzezga, A.; 287 Pohlner, J.; Schoor, M.; Kemp, J. A.; von der Kammer, H. Early-Onset 288 and Robust Amyloid Pathology in a New Homozygous Mouse Model 289 of Alzheimer's Disease. PLoS ONE 2009, 4 (11), e7931. 